\title{
A Critical Review on Importance of Eco-structure Building or Green Building in Bangladesh
}

\author{
Dr. Mostafa Kamal ${ }^{1} \&$ Mohammad Osman Gani ${ }^{2}$ \\ 1 Department of Real Estate, Faculty of Business and Economics, Daffodil International University, Dhaka, \\ Bangladesh \\ ${ }^{2}$ Department of Marketing, Faculty of Business Studies (FBS), Bangladesh University of Professionals (BUP), \\ Dhaka, Bangladesh \\ Correspondence: Mohammad Osman Gani, Department of Marketing, Faculty of Business Studies (FBS), \\ Bangladesh University of Professionals (BUP), Dhaka, Bangladesh. E-mail: osman.gani100@gmail.com
}

\author{
Received: April 6, 2016 \\ Accepted: April 19, 2016 \\ Online Published: May 18, 2016 \\ doi:10.5430/ijba.v7n3p166 \\ URL: http://dx.doi.org/10.5430/ijba.v7n3p166
}

\begin{abstract}
Climate change, caused by the release of greenhouse gases (mainly CO2) into the atmosphere has been recognized as one of the greatest threats of the world. The earth's condition is deteriorating rapidly and it will turn sever unless people adopt eco-friendly policies. Eco-structure building has long been a concept and widely practiced for better living. Bangladesh, having 159.1 million people due to sharp urbanization, population explosion facing severe problem. Up to $40 \%$ of the entire energy level is utilized by the buildings and constructions. It's possible to reduce the amount only by converting the buildings into eco-structure or greening concept. This can provide $50 \%$ saving opportunity to the nation. Importance of building structures in eco-friendly way is now becoming the major concern. Moreover, it has a lot of benefits for the society, economy and human being. Some specific pre-requirements are must be followed before construction. Developer, land owner, consumer as well as the society will be benefitted equally. Through the pace of the urbanization, it's not an easy deal to go through eco-structuring or green building construction. Obstacles regarding eco-structure building with heavy weight population are a constant. People are now concern about better living and healthy environment. This study shows the scenario of rapid population growth, urbanization, importance of green building by finding some obstacles. Recommendations have been suggested on this regard. However, this study will provide some evidence to enrich the existing knowledge in the respective field by collecting data from different sources.
\end{abstract}

Keywords: climate change, greenhouse, eco-structure, deteriorating, urbanization

\section{Introduction}

Buildings and construction activities counts for emission of $40 \%$ carbon dioxide (CO2), one of the main causes of global warming (BCA Report, 2010). Nowadays, we are facing many environmental crises like threat of climate change, the depletion of natural resources, increasing air and water pollution and growing levels of solid wastes. These issues are becoming the major concern in valuing real estate assets and a key driver in the decision making processes. The strategic sustainability process as called "the halo effect" was more worldwide which is affected by the popularity in environmental actions criteria (Mansfield, 2009). Green building has become major topic for the property industry (Robinson, 2007). There have been many terms used of real estate overview for called "sustainable development" such as "green building" (US term), "sustainable building" (UK and Australia term), "sustainable architecture" and "sustainable construction" (Mansfield, 2009; Sayce, 2010). Green building is the practice of constructing environmentally responsible, sustainable and resource-efficient structure for living or other purpose. This includes efficient use of energy, water and other natural resources, protecting health and life, improving employee productivity by reducing waste, pollution and environmental degradation (McManus, 2012 cited from Varma, et al., 2014). "Eco-structuring" enhances sustainability. It benefits humans, community, environment, and a builder's. It is about tailoring a building with the local climate, conditions, culture and community, in order to reduce resource consumption (Karolides, 2002). Green building helps improving environmental footprint by reducing energy by $30-5-\%, \mathrm{CO} 2$ emissions by $35 \%$, waste output by $70 \%$ and water usage by $40 \%$ (McManus, 2012). Now a 
day's eco-structuring is the prime concern of architect because it protects environment, human and gain economic success.

With 159.1 million people, Bangladesh remarks as one of the densely populated country. In this country land prices are high; natural disasters are very frequent. Sturdy found that, permanent housing ratio is barely 3 percent in rural locations whereas 24.28 percent found in urban centers (World Bank, 2014). Estimates suggest a shortage of about 5 million houses in Bangladesh, with as many as 500,000 houses added annually in urban areas and 3.5 million added in rural regions (World Bank, 2014). The need for housing upgrades is also high, given the temporary nature of most dwellings and the slum problem in Dhaka City. Housing supply is not forthcoming, however, except for the upper-income groups catered to by private developers. Some non-government organizations (NGOs) and microfinance institutions (MFIs) fund self-construction for lower-income groups-but on a far smaller scale, relative to the existing need. Government housing provision has not managed to address the issue adequately. Moreover, housing affordability is being eroded by poor land administration policies, which have resulted in very high land prices that make urban housing prohibitive for lower-income groups; and in infrastructure that is inadequate for expansion into per urban and rural areas. In our country public and private housing systems are now growing in a large scale but the most important fact is that, these are not environment friendly in nature as well as these are becoming life threatening to us. So, "look" for a green building that helps to better living is urgent. While natural and resource efficient features can be highlighted in a building construction, they can also be invisible within any architectural design. Living in a green environment that helps to build healthy environment should be the blessing for living. In this study we have discussed about the importance of eco-structure building for the over populated Bangladesh.

\section{Objective}

Broad objective: The objective of this study is to understand and analyze the growing of urban population and showing the importance of eco-structure building for living. The specific objectives of this study are:

\section{Specific Objective:}

1. Figuring the population size and housing size in Bangladesh.

2. To show the importance of eco-structure building by analyzing the goals and benefits.

3. Find out the problems regarding eco-structuring and providing some recommendation regarding the issue.

\section{Methodologies}

In social sciences research the basic instruments for collecting data includes the study of documents, interviews, observations, and questionnaires (Blaxter, Hughes, and Tight, 1997). Corbetta (2003) also argues that,

\section{“...three fundamental actions underlying the techniques of qualitative research are observing, asking and reading".}

This study is basically qualitative in nature based on secondary data. Different national and international published literatures, journals, brochures, articles, researches, case, World Bank report, annual reports, industry news and developments have studied carefully to collect data the list which has been cited in bibliography and reference section of this paper. For better understanding and application of the topic a critical assessment of the existing literatures on the issue is being provided.

\section{Literature Review}

In the $21^{\text {st }}$ century greenhouse gases discharge resulting in climate change (basically carbon dioxide) in the environment (CE Report \& EB Report, 2015), is being marked as the biggest challenge (Perez-Lombard et.al. 2008). In the overall greenhouse gas emission the infrastructural sector hazs been recognized a sthe most outsized contributor (Per-Anders Enkvist, Thomas Naucler and Jerker Rosander, 2007, IPCC, 2007, Nicholas Stern, 2008). Statistics shows that global energy (UNEPSBCI, 2009) consumption in residences, commercial areas, and other buildings (Horvath, 1999) is above $40 \%$. Electric equipment are being used for conditioning the buildings and so the energy consumption is acute (Harvey, 2009). The prediction projects that as India and neighbor countries are in the moderate level the figure will be double (UNEP Kyoto, 2008). It indicates that within 14 years major ecological threats will come for the over populated nations as well as imbalanced unstructured building. Living in a life hazardous place is not expected by all. Green building or eco-structure construction has become major topic (Olanrewaju, 2011) for the property industry (Robinson, 2007). Today; unlike traditional buildings "Green" building has gained popularity in environmental (Zigenfus, 2008 \& Edwards, 2011) and health perspective which consumes major natural sources like energy, water, substances, and surface with more efficiency. Increase of the energy 
efficiency (EPBD, 2002), can have large effects on life-cycle of building. With the demand of developed countries (Matthew E. Kahn, 2009) and sophistication of developing economies (Edward L. Glaeser and Matthew E. Kahn, 2010, Siqi Zheng et al., 2009) the energy efficiency in building will significantly increase with time.

Green buildings or sustainable building (EPA,2013) or 'green potential' (Ben Avraham \& Capeluto, 2011) involves using sustainable methods (Berardi 2013) and materials for planning and structuring properties (or in existing properties renovation) and operations, where the aim is to lower operations and maintenance costs including energy efficiency (EPBD,2002) in lighting technologies and air quality, redeveloping brown field sites, or using green roofs that allow for runoff water to be recycled and also contribute to enriched workforce and student fitness, comfort, and productivity. The global environmental discourse and guiding ecosystem protection (Walsh, 2004; EPA, 2008), reduction or elimination of the negative impact of buildings (LEED, 2004) are being dominated by sustainable development. Though the average additional costs of green buildings require an amount, the advantages of those buildings are comparatively ten times higher. (Kats, 2003; Wiley, 2008; Wiley et. al, 2010).According to Karlenzig, 2005; the procedure of creating buildings and supporting infrastructure is referred to Green buildings that:

1) makes a decrease in resource usage,

2) decreases the negative effects on the environment, and

3) ensures well-conditioned environments for people

Cost savings, developed human performance (including productivity and health), and increased social value (Nalewaik and Venters, 2009) are connected with Green Buildings. Presently people are more concerned about climate change, cost and lack of resources, health issues so they are emphasizing in Eco-structure building (USGBC Report, 2008). According to Federal Environmental Executive of U.S. (2008), "Eco-structure building has developed as a holistic approach and practical answer to the environmental and health burdens of the conventional built environment". Green buildings not only have some commercial benefits, but also have some social and environmental advantages (Yap, 2007). According to one federal report, eco-structure can also be defined as: "the practice of (1) maximizing the efficiency with which buildings and their sites use, generate and recycle energy, water, and materials, and (2) minimizing - and ultimately eliminating - buildings' impacts on human health and the environment, through better sighting, design, construction, operation, maintenance, and removal - the complete building life cycle". Recycled, recyclable and non-toxic are used to build the Eco-structure buildings in order to lowering the effects on environment. ( $\mathrm{Ng}, 2008)$ It is important to keep in mind, a building constructed today will realistically still be standing and in use at least For the next fifty years or more from now (Jablonska et al., 2010) we will be using the buildings constructed today. From the production to the demolition a building's $10-20 \%$ energy consumption depends on the whole process including manufacturing, construction and renovation (UNEPSBCI, 2009). The process of heating and cooling, usage of electric equipment in residential and commercial areas are responsible for $80-90 \%$ of GHG emission (UNEPSBCI, 2009).

With the Gross National Income per capita (GNI), Bangladesh has become a lower-middle income country and the annual incomes rose from $\$ 1,046$ to $\$ 4,125$ (World Bank, 2015). Rural people are moving to urban areas for seeking better living. But accommodation problem is severe here. People with a view of commercial purpose building houses without following building code, 2006. In Bangladesh we have several acts and laws regarding maintaining building code, these are: The Building Construction Act-1952 (EB Act II of 1953), The Town Improvement (TI) Act- 1953, Building Construction Rules-2008, Bangladesh National Building Code (BNBC)-2006, Land Development Rules for Private Housing- 2004. But the people are not following any of these. According to World Bank despite having a population of 15 million people, Dhaka has achieved the pride of being the fastest-growing in the world. The number of the population has increased from 6 to 12 million in between 1990-2005. It is assumed by the U.N. that by 2025 around 20 million people will be living in Dhaka which will turn it into a larger city than Mexico City, Beijing or Shanghai (ECHO, 2010). Many irregular settlements and poor urban planning are done in Bangladesh like other cities in developing countries due to failure in prediction, management and controlling the growth. Moreover, the constructions we have are not environment friendly. In the urban areas buildings are not properly designed with site coverage, garages, access to plot, provision of lift, land use of that particular plot and height of building, fire safety facility, carbon omission reduction facility; as a result living in a building is now at stuck. So, for our country eco-structure with better design, construction, operation, is necessary in order to ensure resources usage, reduction in building impacts on human fitness and environment. Eco-structure is sustainable and beneficial in three basic reasons-it helps in economic growth, its environment friendly and it provides long life service for human being. We have proposed a conceptual framework, that is 


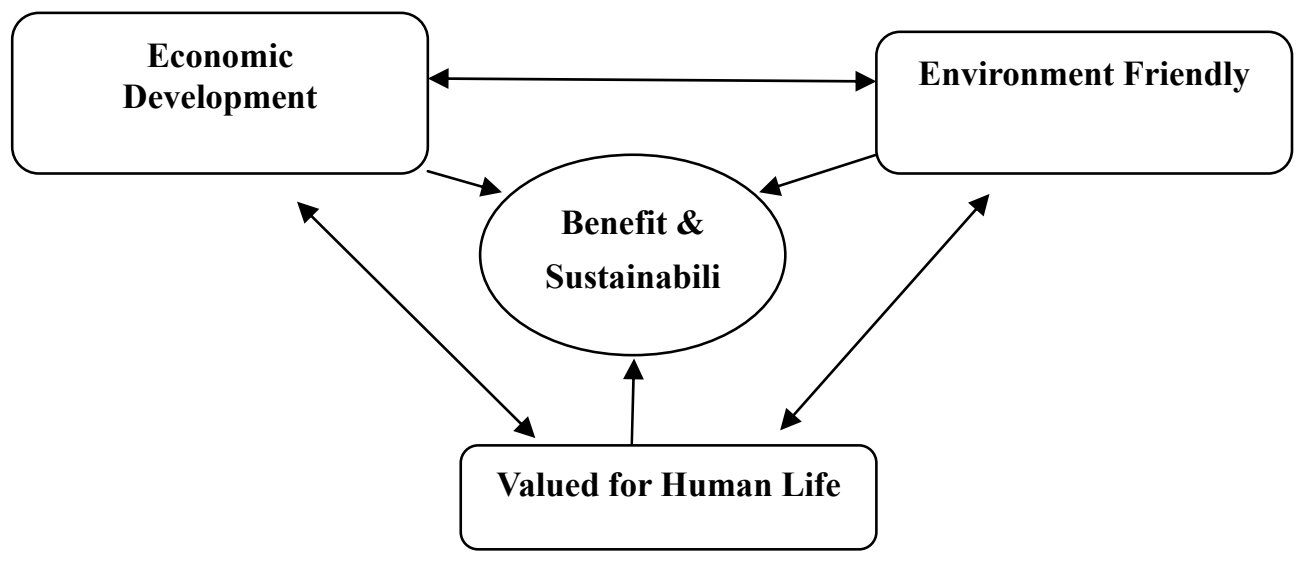

Produced by the authors

Figure 1

A brief review of eco-structure building and green construction shows that for our country eco-structure is necessary in different circumstances, like- use resources -energy, water, and materials - while reducing building impacts on human health and the environment during the building's lifecycle, through better sitting, design, construction, operation, maintenance, and removal. Whereas the number of people are increasing rapidly, to accommodate this overloaded population we need to build eco-structure building on the same pace. The role of governments in highly appreciated in elevating by the experts (Atsusaka, 2003; Samari, 2012). New rules and regulations should be introduced to support green building and the enforcement should be ensured. For the betterment of the next generations Green building is under government's consideration (Sood et al., 2011).

\section{Present Status of Population and Housing}

Since the independence from 1971 despite being a relatively low urbanized country, Bangladesh has witnessed a significant rate of urban growth (Salma A. Shafi, 2010). Bangladesh is making its way from 'rural' to 'urban' being an integral part of the urban transformation. Though the level of urbanization is only 28.4 percent, it already has managed a very large population of 42.7 million in 2011 , living in the countries nearly 570 urban centers (Islam N., 2015). From the World Bank report we can ascertain that, the total number of population is increasing in urban areas in a continuous phase from year to year. Report shows that:

Table 1. Urban population projection

\begin{tabular}{lllll}
\hline $\begin{array}{l}\text { Urban population projection in } \\
\text { Bangladesh 2000 - } 2015 \text { Census } \\
\text { Year }\end{array}$ & $\begin{array}{l}\text { Total } \\
\text { National } \\
\text { Pop }^{\mathbf{n}}\end{array}$ & $\begin{array}{l}\text { Total } \\
\text { urban } \\
\text { Pop }^{\mathbf{n}}\end{array}$ & $\begin{array}{l}\text { Urban pop as \% of total Pop } \\
\text { (level of urbanization) }\end{array}$ & $\begin{array}{l}\text { Annual Urban } \\
\text { Growth (\%) }\end{array}$ \\
\hline 2000 & 141.1 & 37.3 & 26.4 & 4.8 \\
\hline 2005 & 155.8 & 46.4 & 29.8 & 4.4 \\
\hline 2010 & 170.5 & 56.8 & 33.3 & 4.0 \\
\hline 2015 & 184.6 & 67.9 & 36.8 & 3.6 \\
\hline
\end{tabular}

Source: World Bank, Bangladesh Economic and Social Development Prospects (Report No. 5407),

From SANEI Report, 2013 it is estimated that , projections, keeping in mind the growth rates of population observed during 2001-2011 and based on the UN population projection model, indicate that Bangladesh would achieve 'the tipping point' of 50 per cent urban by 2047. Population of Bangladesh is increasing day after day. Thus, Bangladesh is expected to be majority 'urban' within the next 35 years (Islam N, 2015). 


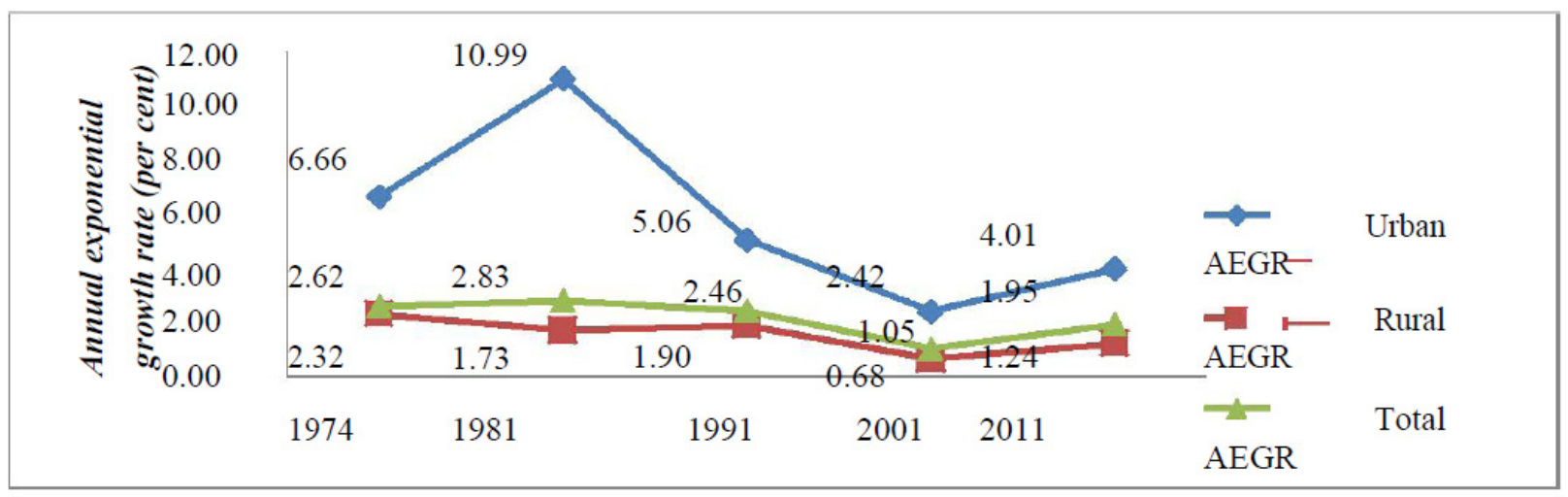

Source: Bangladesh Census and estimations, 2011.

Figure 2. Annual growth rates of population: urban, rural and total: 1974-2011

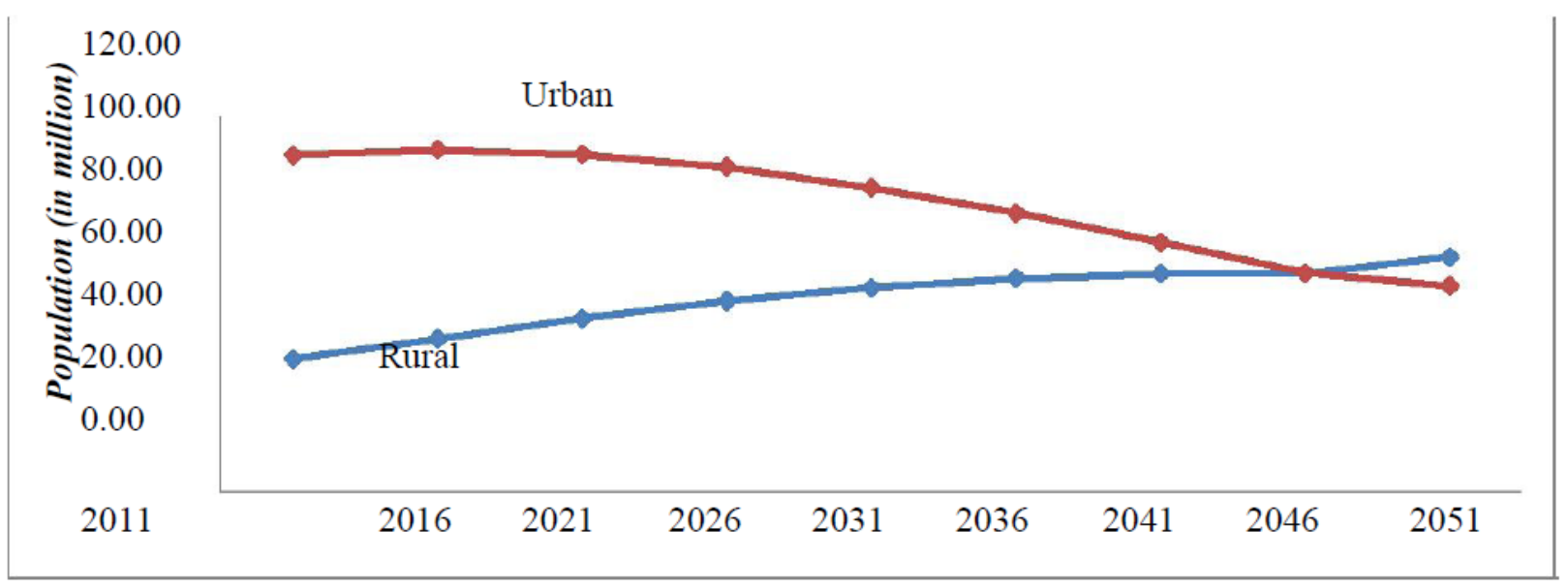

Source: Bangladesh Census, and estimations, 2011.

Figure 3. Growth rate of rural and urban population

Bangladesh is still a predominantly rural nation, but urbanization has gathered pace, especially in the recent years. Bangladesh has an urban population of 42.7 million in the year of 2011. As some changes were done in the Census definition of urban, the country experienced a remarkable change in the urban population in the year of 1981. In 2011 it has seen noticed that the urban population has jumped by almost 6.8 times where rural population has jumped by 1.7 times in the 37 years after the first Census conducted in 1971. The level of urbanization has jumped from 8.78 to 28.37 in this period. The growth rate of urban population over the period 1974-2011 has been 5.18 per cent, as against only 1.36 per cent of the rural population (SANEI Report, 2013); 
Table 2. Urban growth rate differential

\begin{tabular}{|c|c|c|c|c|c|c|}
\hline Year & $\begin{array}{l}\text { Urban } \\
\text { Population } \\
\text { (in million) }\end{array}$ & $\begin{array}{l}\text { Rural } \\
\text { Population } \\
\text { (in million) }\end{array}$ & $\begin{array}{l}\text { Percentage } \\
\text { Urban }\end{array}$ & $\begin{array}{l}\text { Urban } \\
\text { annual } \\
\text { exponential } \\
\text { growth rate } \\
\text { (per cent) }\end{array}$ & $\begin{array}{l}\text { Rural } \\
\text { annual } \\
\text { exponential } \\
\text { growth rate } \\
\text { (per cent) }\end{array}$ & $\begin{array}{l}\text { Urban } \\
\text { Rural } \\
\text { Growth } \\
\text { Differential } \\
\text { (AEGR) }\end{array}$ \\
\hline 1901 & 0.70 & 28.23 & 2.43 & -- & -- & -- \\
\hline 1911 & 0.81 & 30.75 & 2.56 & 1.39 & 0.86 & 0.54 \\
\hline 1921 & 0.88 & 32.38 & 2.64 & 0.85 & 0.52 & 0.33 \\
\hline 1931 & 1.07 & 34.53 & 3.02 & 2.00 & 0.64 & 1.36 \\
\hline 1941 & 1.54 & 40.46 & 3.66 & 3.59 & 1.58 & 2.01 \\
\hline$\overline{1951}$ & 1.82 & 40.24 & 4.33 & 1.69 & -0.05 & 1.74 \\
\hline 1961 & 2.64 & 48.20 & 5.19 & 3.72 & 1.80 & 1.92 \\
\hline$\overline{1974}$ & 6.27 & 65.21 & 8.78 & 6.66 & 2.32 & 4.33 \\
\hline$\overline{1981}$ & 13.54 & 73.58 & 15.54 & 10.99 & 1.73 & 9.26 \\
\hline 1991 & 22.46 & 89.00 & 20.15 & 5.06 & 1.90 & 3.16 \\
\hline 2001 & 28.61 & 95.25 & 23.10 & 2.42 & 0.68 & 1.74 \\
\hline 2011 & 42.70 & 107.80 & 28.37 & 4.01 & 1.24 & 2.77 \\
\hline
\end{tabular}

Source: Bangladesh Census and estimations

A rapid increase in population is noticed in the urban areas. Inhabitants number per square kilometer determines the density of population. According toThe 2011 Census Preliminary Results, in Bangladesh, 964 of inhabitants live per square kilometers (the density in 2001 was 834 ). No other country has the population density like Bangladesh in the whole wide world. Even the household number is also increasing with the same pace. During the census A total number of 32,067,700 households have been listed; among them "General" households represent 98.5\%. The category "Others" households counts for $1.1 \%$ while the share of "Institutional" households is less than $1 \%$ of the total count (BBS, Census, 2011).

Table 3. Average household size by residence, $1974-2011$

\begin{tabular}{lllllll}
\hline Locality & \multicolumn{3}{c}{ Year } & \multicolumn{3}{c}{ Year } \\
\cline { 2 - 7 } & $\mathbf{1 9 7 4}$ & $\mathbf{1 9 8 1}$ & $\mathbf{1 9 9 1}$ & $\mathbf{2 0 0 1}$ & $\mathbf{2 0 0 4}$ & $\mathbf{2 0 1 1}$ \\
\hline & Census & Census & Census & Census & Survey & Survey \\
\hline $\mathbf{1}$ & $\mathbf{2}$ & $\mathbf{3}$ & $\mathbf{4}$ & $\mathbf{5}$ & $\mathbf{6}$ & $\mathbf{7}$ \\
\hline Total & 5.64 & 5.75 & 5.48 & 4.87 & 4.66 & 4.35 \\
\hline Rural & 5.62 & 5.73 & 5.48 & 4.89 & 4.68 & 4.36 \\
\hline Urban & 5.89 & 5.86 & 5.49 & 4.86 & 4.57 & 4.29 \\
\hline
\end{tabular}

Source: BBS, Bangladesh Population and Housing Census, 2011.

The household is densely populated overtime. The urban areas are not suitable for living. Unplanned housing and living are seems to be the burden for the next generation. So, building houses by maintaining the code and eco-structure is mandatory for us.

\section{Importance of Eco-structure Building}

The complete system of true eco-structure building comes up with programming, planning, designing, and constructing (or renovating) buildings and sites. It also connects often-interlinked issues such as site and climate, building orientation and form, lighting and thermal comfort, materials, etc., and optimizing all these aspects in concert. The operation costs area being reduced by minimizing waste and reducing the dependency on expensive fossil resources. According to Fuerst and McAllister (2009), the owner can have the benefits from increased 
occupancy rates $(+8 \%)$, higher rents $(+6 \%)$ and higher building values $(+35 \%)$. The overall impact of the built environment on human health and the natural environment can be reduced by the Eco-structures by:

1) Using energy, water, and other resources efficiently

2) Protecting occupant health and employee productivity

3) Minimizing waste, pollution and environmental degradation

Environment on human health and the natural environment by:

1) Efficiently using energy, water and other resources

2) Protecting occupant health and improving employee productivity

3) Reducing waste, pollution and environmental degradation

Some of the underlying factors driving green building forward suggested from ILO Report, 2013. Some are interrelated and mutually dependent factors:

a) To respond to the threat of climate change the carbon emissions from buildings should be lower

b) Broader issues of sustainability which includes the need to conserve water

c) Desire to minimize the environmental impact of buildings energy prices and energy security

d) Environmental awareness among the people

e) Population growth, urbanization and improving living standards

f) Employment creation in the economic crisis

g) Comfort

h) Quality of the existing stock of buildings

i) Ecological sanitation

Source: ILO, 2013: Skills and Employability Department, European Union

6.1 Goals of Establishing Eco-structure Building

1. More energy efficient and environmentally friendly construction practices.

2. Design Efficiency.

3. Energy Efficiency.

4. Water Efficiency.

5. Materials Efficiency.

6. Indoor environmental quality enhancement.

7. Operations and maintenance optimization

8. Waste and toxics reduction.

9. Specify 'green' building materials from local sources.

10. Reduce loads.

11. Optimize systems.

12. Generate on-site renewable energy.

13. Wind towers to increase air circulation.

14. Use layers of walls-external layer of stones and internal layer of bricks.

15. Rat traps design for the circulation of air between these layers.

16. Mosaic Tiles \& Albedo Thermoshield roofing to reflect temperature.

17. Waterproof roof top garden.

18. Recycled water by Root Zone System.

19. Usage of wind turbines and solar panels on roof for generate energy.

20. Solar powered water pumping station. 
21. Rain harvesting

22. Toilets with Blue Seal

23. Solar power generation unit

24. The mechanism of Water harvesting method

25. Solar photovoltaic installation on rooftop

26. Minimal carbon dioxide emission

27. Using sunlight for lighting

28. Indoor climate control mechanism.

We can convert any building into eco-structure by adding the above features. Studied found that; eco-structure building have some specific goals (Kats et al., 2003; RICS, 2005; Green Building Council of Australia, 2008) which provides;

a. are more energy efficiency;

b. have lower operating and maintenance costs;

c. provides better comfort and well-being for occupants;

d. are more marketable than conventional buildings;

e. have lower risk potential; and

f. Reduced negative impact on the environment.

\subsection{Main Features for Housing in Eco-structuring}

1. Using river, which reduce the transportation cost.

2. Build the structure without change the natural shape of the land and without change the crops land.

3. Establish the bio gas plant.

4. Use the solar energy.

5. Use the vehicles locally, which are not creating any toxic gas.

6. Establish the power plant for electricity.

7. Establish the cold storage for farmer.

8. Establish the dairy and firm facility.

9. Use the waste by transformation them into fertilizer.

This building is also the only such structure that does not use air conditioning despite being situated in a hot place like Gulbarga where the mercury hurtles past the 40 degrees mark in summer.

\subsection{Pre-requirement for Eco-structure Building Construction}

It's possible to fabricate any building in eco-friendly way but for longevity it's better to follow some instruction before the development. Three are some instructions to be followed given below. 
Table 4. Fundamental instruction

\begin{tabular}{|c|c|c|}
\hline Serial & Concern & Instruction \\
\hline 1 & $\begin{array}{l}\text { Environmental organization } \\
\text { of sites }\end{array}$ & $\begin{array}{l}\text { - } \text { Choice of site } \\
\text { - } \text { Alternative transport modes } \\
\text { - } \text { Fluidity on site } \\
\text { - } \text { Minimal disruption caused by site } \\
\text { - } \text { Rain water management } \\
\text { - } \text { Site layout to reduce the effects of a thermal island } \\
\text { Reduction of light pollution }\end{array}$ \\
\hline 2 & Efficient water management & $\begin{array}{l}\text { - Innovative waste water treatment technologies } \\
\text { - Reduction in water consumption }\end{array}$ \\
\hline 3 & Energy and atmosphere & $\begin{array}{l}\text { - Optimize energy performance } \\
\text { - Renewable energies } \\
\text { - Improve refrigerant management } \\
\text { - Measure and verify } \\
\text { - Green energy } \\
\text { - } \text { Protect the ozone layer } \\
\end{array}$ \\
\hline 4 & Materials and resources & $\begin{array}{l}\text { - } \text { Reuse buildings } \\
\text { - } \text { Management of construction waste } \\
\text { - Reuse of materials } \\
\text { - Recycled content } \\
\text { - Regional materials } \\
\text { - } \text { Certified wood } \\
\end{array}$ \\
\hline 5 & $\begin{array}{l}\text { Quality of interior } \\
\text { environments }\end{array}$ & $\begin{array}{l}\text { - } \text { CO2 checks } \\
\text { - Increased ventilation } \\
\text { - Interior air quality management plan } \\
\text { - Low-emission materials } \\
\text { - Control of interior sources of chemical emissions and pollutants } \\
\text { - System control by occupants } \\
\text { - Thermal comfort } \\
\text { - Natural light and views }\end{array}$ \\
\hline
\end{tabular}

Source: proposed by the authors.

Instructions are mandatory to be followed. For the betterment of living in a natural and healthy way it's obvious to build a house by following eco-structure. There is a global crisis of eco-structure building. People consuming the energies without thinking alternative sources or even renewable sources. The commercial and residential construction sector can represent up to $40 \%$ of primary energy consumption. Overall, it is also responsible for 20 to $25 \%$ of waste dumped and 5 to $12 \%$ of total water consumption (Renaud, 2014). It is considered that on average, green building currently reduces energy consumption by $30 \%$, carbon emissions by $35 \%$, water consumption by $30 \%$ to $50 \%$, costs relating to waste by $50 \%$ to $90 \%$ (USGBC, 2015). Three basic things are important in eco-structure or green building construction:- resources, pollution and performance (Berge, 2000). According to Albino, Balice \& Dangelio (2009), a green building material is one that minimizes environmental impact throughout its entire life cycle. Attmann (2009) states that green materials are: environmentally friendly, renewable, biodegradable, and recyclable. Attmann (2009) again discussed about the green materials to be concerned: biomaterials (biotic materials), e.g. straw, carbon, polyurethane; composites, e.g. concrete, brass; smart materials, e.g. carbon-fibre, and nano-materials, e.g. nano-carbon tubing. From the study of Kelly \& Hunter (2009) they proposed three R's (reduce, re-use and recycle) as being helpful in selecting as eco-structure building materials. 


\subsection{Advantages of Eco-structure Building}

It has been assumed that energy efficiency in building and appliances can reduce $1.6 \mathrm{Gt} \mathrm{CO} 2$ in 2020 and up to $7 \mathrm{Gt}$ CO2 in 2050 (Ramesh S P \& Emran Khan M, 2013). To diffuse the energy efficiency technologies globally, about $\$ 158$ billion per annum between 2010 and 2050 are required. According to study by McGraw Hill Construction, about half of new global commercial building projects will be planned as green buildings and $45 \%$ of retrofitting projects on existing buildings are targeted to improve energy performance. The fastest growing regional green building market is Asia in terms of region, as the population of firms largely dedicated to green building is expected to jump from $36 \%$ today to $73 \%$ in 2013 . More than half study firms reaexpected to be largely dedicated to green building (on over $60 \%$ of projects), up from $30 \%$ today. The steady growth in sales and profit levels associated (GBC India, 2007) with green building is expected over $85 \%$ firms. Both the energy efficiency as well as opportunities for economic investment divergence are brought by GB. The benefits of eco-structure buildings require reduced capital investments, reduced operating costs, reduced personnel costs, and increased operating revenue, increased occupancy and net metering, Furr(2009). The reduction in energy and water use can be emphasized as an advantage (Srinivas, 2009: 795), while Furr (2009: 104) emphasized the cost advantages. Developing a building in eco-structure way is advantageous for all. It is a combined success. It is beneficial for the landowners, developers, customers and country. Advantages of eco-structure building are given below:

\subsection{Advantage of Land Owner}

When the landowner can't bear the whole establishment cost of a building, he can share the land with the developer. From this,

1. Land owner can get $30 \%-50 \%$ of build able area without any cost.

2. Land owner can get rent facility.

3. Land owner can run agro business by help of developers on the top roof and even on the lobby.

4. Land owner can live a standard life which he can't get by his own capacity.

\subsection{Advantage of Developers}

1. Developers can get $50 \%-70 \%$ of build able area.

2. Developers can get low construction cost because the land facility is already given by the owner.

3. Developers can get low transportation cost in village by using river.

4. Developers can get sufficient customer easily for product.

5. Developers can run agro business in the building.

\subsection{Advantage of Buyer/Consumer}

1. Consumer can get healthy standard life in local area.

2. Consumer can get proper natural environment facility in their living place.

3. Consumer can get same facility like city low cost.

4. Consumer can get low cost facility in transportation.

5. Consumer can live near their work place with standard life.

\subsection{Advantage of Society or Country}

1. It reduces the density of population in urban area.

2. It creates the decentralization environment in the country.

3. It spread the development among the whole country.

4. It will force the govt. to develop the transportation in the local area.

\section{Obstacles to Eco-structuring in Urbanization}

For the economic growth and socio-cultural development urbanization with eco-structure creation has been found to be an effective engine worldwide. Economically urbanization contributes significantly to the national economy. This sector contributes to more than 65 percent of the GDP (ADB, City Cluster Economic Development: Bangladesh Case 
Study, 2010) in Bangladesh (at 28 percent urban). An apparent co-relation is noticed between regional economic developments with level of urbanization. The districts with higher level of urbanization also happen for the economic development. This trend may lead one to wrap up that urbanization on a macro-scale would be beneficial to the economy of Bangladesh. The average investments in the infrastructures, whether through new construction or refurbishment, can have some of the most long term impacts on the competitiveness of our city in everywhere in the world. An upfront investment of only 2 per cent in green building design, on average, can result in life cycle savings of 20 per cent of the total construction costs - more than ten times the initial investment (Kats, G. 2003). Comparing to the average commercial building, (GSA Public Buildings Service, 2008), the cost benefits of green buildings (GBSMR, 2006) are appreciated and include 8-9 per cent decrease in operating costs, 7.5 per cent increase in building value, 6.6 percent improvement in return on investment, a 3.5 per cent increase in occupancy ratio, and a 3 per cent increase in rent ratio. A wider adoption of technologies and practices are holdback for greening the construction sector as a number of barriers and negative incentive structures are there. Here Table:05 summarizes the main impediments for energy-efficiency measures, which are equally valid for water efficiency Based on the classification suggested by The Carbon Trust (2005) and further adapted by Levine, Ürge-Vorsatz et al (2007).

Table 5. Barriers to eco-structure building in energy-efficiency

\begin{tabular}{|c|c|c|}
\hline Category & Definition & Barriers \\
\hline $\begin{array}{l}\text { Financial } \\
\text { cost- benefit }\end{array}$ & $\begin{array}{l}\text { Ratio of investment cost to value } \\
\text { of energy savings }\end{array}$ & $\begin{array}{l}\text { a) Costs of advanced equipment } \\
\text { b) Incomplete opportunities in financing } \\
\text { c) Allocation of energy } \\
\text { d) Borderline costs (environment, health) } \\
\text { e) Non specified in price }\end{array}$ \\
\hline $\begin{array}{l}\text { Hidden } \\
\text { cost-benefit/ } \\
\text { transaction } \\
\text { costs }\end{array}$ & $\begin{array}{l}\text { Cost or risks (real or perceived) } \\
\text { that are associated to change and } \\
\text { not captured in standard cost } \\
\text { benefit analysis }\end{array}$ & $\begin{array}{l}\text { a) Probable costs and risks associated with } \\
\text { incompatibility, performance and other } \\
\text { transaction costs } \\
\text { b) Costs or risks of remaining the same } \\
\text { c) Obsolescence, change in consumption } \\
\text { d) designs, new legislation }\end{array}$ \\
\hline $\begin{array}{l}\text { Market } \\
\text { Imperfections }\end{array}$ & $\begin{array}{l}\text { Market structures and constraints } \\
\text { which prevent the consistent } \\
\text { trade-off between energy-efficient } \\
\text { investment and the societal } \\
\text { energy-saving benefits }\end{array}$ & $\begin{array}{l}\text { a) Principal agent dilemma } \\
\text { b) Fraction in market structure } \\
\text { c) Regulatory defaults } \\
\text { d) Fault in information }\end{array}$ \\
\hline Behavior & $\begin{array}{l}\text { Behavioral characteristics of } \\
\text { individuals and organizations }\end{array}$ & $\begin{array}{l}\text { a) Business as usual behavior and lifestyle } \\
\text { b) Lack of awareness } \\
\text { c) Corruption }\end{array}$ \\
\hline
\end{tabular}

Source: Carbon Trust (2005) and Levine, Ürge-Vorsatz et al (2007)

According to Anderson, Bidgood \& Heady (2010), construction of green building is different from that of conventional buildings, but as with conventional construction, claims and disputes also accompany green projects as it has several risks (Bowers \& Cohen, 2009). From the analysis of Geoff Bilau (2008) the most important challenges facing by the green building industry are

1) Lack of non-segregated ground plan

2) Green education

3) Resistance to change

4) Building with greening

5) Limited post occupancy estimation

6) Lack of transit orient improvement 
7) Split incentives for owner-tenant

8) Separate capital and operating budgets.

Especially when Eco-structuring takes place at a pace as rapid as the one in evidence in Bangladesh, it has to face some challenges. The current and future challenges of green building in Bangladesh are many, we have identified some reasons:

\section{The Challenges are:}

1) The excessive National and Urban Population: Present and Future

2) High-quality and expensive eco-conscientious materials.

3) Regional / Spatial Imbalance in Urbanization

4) The Urban Economy: Productivity and Competitiveness, Formal and Informal Sector Dichotomy, Employment -Inequality in income and Poverty.

5) Inequal access to land and housing. Housing for the low income groups are growing without proper planning.

6) Lack of proper housing education and skill development

7) Transportation and Traffic problems are acute in Bangladesh.

8) Environmental Management: Pollution (Water, Air, Sound and Visual), Climate Change Impact, Environmental Hazards.

9) Social and Political Conflicts, Crime and Violence, Cultural and Religious Conflicts, law and order situation

10) Problems of Special Groups: Aged, Children, Women, Physically Challenged, Marginal Groups

11) Urban Financial Resource Constraints: Poor-per capita Public Investment

12) Institutionalizing, Urban Visioning, Policy, Urban Planning and Planned Urban development, Research, Information.

\section{Recommendation}

The National Urban Policy intends to strengthen the beneficial aspects of urbanization and effectively deal with its negative consequences at the same time to achieve sustainable urbanization, keeping in view the multi-dimensional nature of the urbanization process. The policy also envisions a decentralized and participatory process of urban development consists of the central government, the local government, the private sector, the civil society and the people having their roles to play. Some recommendations regarding the eco-structuring are given below:

a) Through decentralized development and hierarchically structured urban system with green concept balanced ecology and urbanization can be ensured;

b) Facilitate environmental development, economic development, employment generation, reduction of inequality and eradication of poverty through appropriate regulatory frameworks and infrastructural provisions;

c) Ensure maximum utilization of land resources by side to side open plantation system and meet increased demand for housing and urban services through public-private and other partnerships;

d) Protect, preserve and enhance the urban environment, particularly water bodies;

e) To ensure and maintain planning code with environment consciousness, local governments should be strengthen by providing appropriate powers, resources and capabilities so that these can take effective responsibility in planning, infrastructure provision, service delivery and regulatory functions ;

f) All sectors of the community, including women and the poor, should be involved in decision-making and implementation processes;

g) Prioritize the particular needs of women, men, children, youth, the aged and the disabled in developing a building that suits for living in a natural way;

i) Assure health, safety and security of all citizens by taking multifaceted initiatives to reduce crime and violence;

j) To enhance their ravishing beauty of the historical and cultural heritage of cities it should be protected, preserved and improved

k) Develop and implement urban management strategies and governance arrangements for enhancing complementary roles of urban and rural areas in sustainable development; and 
1) By enhancing transparency and establishing accountability good governance can be ensured.

$\mathrm{m})$ Reducing waste, pollution and harm to the environment.

n) Government can introduce green tax system.

o) We can follow the LEED (Leadership in Energy \& Environmental Design) concept to ensure perfect design. LEED is an ecology-oriented building certification program run under the US Green Building Council (USGBC).

\section{Conclusion}

While managing urban growth, urban expansion and urban development, Bangladesh faces enormous challenge. To battle climate change, reduce energy bills, and diminish our reliance on fossil fuels it is mandatory to construct new eco-friendly projects, renovate existing construction in ecofriendly buildings which will also lower the cost. In an up growing trend of population, it is obvious to follow eco-structure for our well being. Goals of eco-structure construction can be attainable if there is cooperation between the public-private partnerships. By embracing the future and the change it will bring, we will achieve a balance between ourselves, our lifestyles, and our environment. Though Bangladesh will be an urbanized country in demographic statistical term in less than four decades from now, but the nature of urbanism in the future remains rather indefinable. Political and cultural bindings, the threat of the climate change phenomenon and the crisis of governance at the national as well as urban local levels, all tend to make one feel uncomfortable, to state the least. Though we are facing acute urbanization problem, we have the hope to grow up with eco-constructive city within a few decades.

\section{References}

Albino, V., Balice, A., \& Dangelio, R.S. (2009). Environmental strategies and green product development: An overview on sustainability driven companies. Business Strategy and the Environment, 18(2), 83-96.

Anderson, M.K., Bid good, J.K., \& Heady, E.J. (2010). Hidden legal risks of green buildings. Florida bar Journal, 84(3), 35-41.

Atsusaka, N. (2003). Growing the Green Building Industry in Lane County - a report for the lane county sustainable business and job project, report prepared from the program for Watershed and Community Health, Institute for a Sustainable Environment, University of Oregon, USA.

Attmann, O. (2009). Green architecture-advanced materials and technologies. New York: McGraw-Hill.

BBS -Bangladesh Bureau of Statistics. (2011). Population and Housing Census, Statistics and Informatics Division (SID), Ministry of Planning.

BCA-Building and Construction Authority. (2010). The Centre for Sustainable Buildings and Construction, Building and Construction Authority, ISBN 978-981-08-5313-6.

Ben Avraham, O., \& Capeluto, I. G. (2011). A tool for determining the green potential of existing buildings. Paper presented at the PLEA 2011 - 27th Conference on Passive and Low Energy Architecture, Louvain-la-Neuve, Belgium.

Berardi, U. (2013). Clarifying the new interpretations of the concept of sustainable building. Sustainable Cities and Society, 8, 72-78. http://dx.doi.org/10.1016/j.scs.2013.01.008

Blaxter, L., Hughes, C., \& Tight, M. (1997). Education, Work and adult life: how adults relate their learning to their work, family and social lives. In Sutherland, P. (Ed.), Adult Learning: A Reader (pp. 30-43). London, Kogan.

Bowers, K., \& Cohen, L. (2009). The green building revolution. Environmental law \& policy clinic: Havard Law $\begin{array}{lllllll}\text { School, } & 10 & \text { March. } & \text { Retrieved } & 10 & \text { June } & \text { 2010, }\end{array}$ http://www.mgkflaw.com/Green\%20Building\%20Revolution.pdf

Carbon Trust. (2005). The UK Climate Change Program: Potential evolution for business and the public sector. London.

Civil Exchange Report. (CE-2014). Submission on a proposal on the mandatory implementation of the building energy codes. Retrieved 15 September 2014, from http://www.civicexchange.org/eng/publication.aspx

EB Act II of 1953. After independence of Pakistan in 1947 the cities were growing rapidly. The 1932 Bengal Municipal Act, 1932 was the only regulation for building control. To address the situation the government promulgated the EBBC ordinance, 1951 which was later re-enacted as the EBCC Act, 1952; Amended in 1952, 1984, 1996, 2006, 2007; Created an efficient, autonomous agency which was Dhaka Improvement Trust (DIT) in 1956 and became RAJUK through an amendment in 1987. 
ECHO. (2010). Urban Risk Assessment, A Facilitators Guidebook, European Commission Humanitarian Aid Office (ECHO).

Edwards, B. (2011). Distinctions of green, eco, bio-climatic and sustainable design. RIBA: Architecture.com "Sustainability Hub". Retrieved from http://www.architecture.com/SustainabilityHub/Designstrategies/Introduction/1-0-2Distinctionsofgreen,eco,bioclimaticandsustainabledesign.aspx

Enkvist, Per-Anders, Thomas Naucler, \& Jerker Rosander. (2007). A Cost Curve for Greenhouse Gas Reduction. The McKinsey Quarterley, 1, 35-45.

Environmental Bureau (EB). Policy and consultation papers: a proposal on the mandatory implementation of the building energy codes. $\quad$ Retrieved 15 December 2011, from http://www.enb.gov.hk/en/resources_publications/policy_consultation/building_energy_codes.html

EPA Report. (2013). Definition of Green Building. Retrieved 12 May 2013, from http://www.epa.gov/greenbuilding/pubs/ about.htm

EPBD. (2002). Directive 2002/91/EC of the European Parliament and of the Council of 16 December 2002 on the energy performance of buildings. Retrieved Retrieved 12 May 2013, from http://eurlex.europa.eu/legalcontent/EN/TXT/?uri=CELEX:32002L0091

Fuerst, Franz, \&Patrick McAllister. (2008). Does it pay to Be Green? Connecting Economic and Environmental Performance in Commercial Real Estate Markets. The University of Reading, Business School.

Furr, J.E. (2009). Green building and sustainable development: The practical legal guide. Chicago: American Bar Association Publishing.

Geoff Bilau. (2008). 8 Challenges Facing the Green Building Industry.

GSA Public Buildings Service. (2008). Assessing Green Building Performance: A Post Occupancy Evaluation of 12 GSA Buildings.

Harvey. (2009). Global warming and the energy efficiency of Spanish industry. Energy Econ, 24(4), 405-23.

Horvath, A. (1999). Construction for Sustainable Development - A Research and Educational Agenda. Submitted for the Berkeley-Stanford Construction Engineering and Management Workshop, August 26-28.

ILO Report. (2013). Skills and Employability Department. European Union.

Islam, N. (2015). Urbanization in Bangladesh: Challenges and Opportunities. NEC Conference Room, Planning Commission, Dhaka, 8-9 April 2015.

Kahn, Matthew E. (2009). Urban Growth and Climate Change. Annual Review of Resource Economics, 1, 333-49.

Kahn, Matthew E., \& Matthew J. Kotchen. (2010). Environmental Concern and the Business Cycle: The Chilling Effect of Recession. NBER Working Paper \#16241.

Karlenzig, Warren. (2005). A blueprint for greening affordable housing: Developer guidelines and resource efficiency and sustainable communities. Santa Monica, California: Global Green USA.

Karolides, A. (2002). An Introduction to Green Building, Part 1: Resource Efficiency. RMI Solution: 2002.

Kats, G. (2003). Green Building Costs and Financial Benefits. Massachusetts Technology Collaborative.

Kats, G. (2003). The Costs and Financial Benefits of Green Buildings: A Report to California's Sustainable Building Task Force.

Mansfield, J. (2009). The Valuation of Sustainable Freehold Property: A CRE Perspective. Journal of Corporate Real Estate, 11(2), 91-105.

McGraw Hill Construction, Green Building SmartMarket Report, 2006.

McManus, B. (2012). Green Buildings Certifications, an Overview and Strategic Guidance for Schneider Electric Employees.

Nalewaik, A., \& Venters, V. (2009). Cost Benefits of Building Green. Cost Engineering, 51(2), $28-34$.

Newsletter on Green Building From Indian Green Building Council, September 2007 Issue.

Ng, C. (2008). Constructing a green building. Malaysian Business. 
Office of the Federal Environmental Executive, the Federal Commitment to Green Building: Experiences and Expectations, p. 8. Retrieved from http://www.ofee.gov/sb/fgb_report.pdf

Olanrewaju, A. A. (2011). Green maintenance management initiative for university buildings. Built Environmental Journal, 8(1), 17-24.

Perez-Lombard, et. Al.. (2008). A Review on Building Energy Consumption Information. Energy and Building, 40, 394-398.

Ramesh, S. P., \& Emran, K. M (2013). Energy Efficiency in Green Buildings -Indian Concept. International Journal of Emerging Technology and Advanced Engineering, 3(3), Special Issue. ICERTSD 2013, Feb 2013, 329-336. Retrieved from www.ijetae.com

Renaud, B. (1994). Global Real Estate Cycles: An Overview. Journal of Real Estate Literature, 5, 13-44.

Retrieved from http://www.worldbank.org/en/country/bangladesh

Robinson, J. (2005). Property Valuation and Analysis Applied to Environmentally Sustainable Development. PRRES.

Sayce, S., \& Sundberg, A. (2010). Is Sustainability Reflected in Commercial Property Prices: A Review of Existing Evidence?. Journal of RICS Sustainability.

Sood, M. S., Chua, H. K. M., \& Peng, Y. L. (2011). Sustainable Development in the Building Sector: Green Building Framework in Malaysia. ST-8: Best Practices \& SD in Construction.

Srinivas, S. (2009). Green buildings - Benefits and impacts. Proceedings of World Academy of Science, Engineering \& Technology, 19-21 March.

The World Bank. (2010). Expanding Housing Finance to the Underserved in South Asia, Market Review and Forward Agenda by Tatiana Nenova.

UNEP, United Nations Environment Programme. (2008). The Kyoto Protocol, The Clean Development Mechanism and Building the Construction Sector. Retrieved 3 March 2014, from http://www.unep.org/sbci/pdfs/BuildingsandCDMreporteversion.pdf

UNEPSBCI, United Nations Environment Program Sustainable Buildings and Climate Initiative. (2009). United Nations Environment Program Buildings and Climate Change: Summary for Decision Makers. Retrieved 28 February 2014, from http://www.unep.org/sbci/pdfs/sbci-bccsumma ry.pdf

Ürge-Vorsatz, D. et al.. (2010). Employment Impacts of a large-scale deep building energy retrofit program in Hungary. Center for Climate Change and Sustainable Energy Policy of Central European University (3CSEP) (Budapest, Central European University).

USGBC Research Committee. (2008). A National Green Building Research Agenda, November, 2007.

USGBC. (2015). United States Green Building Council.

Varma, et al.. (2014, February). Green Building Architecture: A Literature Review on Designing Techniques. International Journal of Scientific and Research Publications, 4(2).

Walsh, C. J. (2004). Rio de Janeiro Declaration on Sustainable Social Development, Disability \& Ageing. Designing for the $21^{\text {st }}$ Century III Rio de Janeiro, Brazil: 7th - 12th December, 2004.

Wiley, J., Benefield, J., \& Johnson, K. (2010). Green Design and the Market for Commercial Office Space. Journal of Real Estate Finance Econ, 41, 228-243.

Yap, Y. J. (2007. October 29). City \& Country: Moving in the green direction. The Edge Daily.

Zigenfus, R. E. (2008). Element analysis of the green building process. (M.S. 1460281), Rochester Institute of Technology, United States -- New York. Pro-Quest Dissertations \& Theses (PQDT) database. Retrieved from http://search.proquest.com/docview/89311507?accountid=28930 